\title{
Gambaran Tingkat Pengetahuan Mahasiswa Fisioterapi STIKVINC Tentang Insole Sebagai Alternatif Menurunkan Kadar Gula Darah
}

\author{
Ignasius Heri Dwianto \\ Dosen Stikes Katolik St. Vincentius a Paulo Surabaya \\ Email: heri594@yahoo.co.id
}

\begin{abstract}
ABSTRAK
Penelitian terdahulu menyatakan bahwa pemakaian insole dengan sudut $-10^{\circ}$ selama 5 hari terjadi penurunan kadar glukosa darah puasa dan kadar glukosa darah post prandial. Berdasarkan pengamatan peneliti tidak semua mahasiswa fisioterapi tahu tentang insole sebagai alternatif menurunkan kadar gula darah. Penelitian ini mengidentifikasi tingkat pengetahuan (tahu) mahasiswa fisioterapi tentang insole sebagai alternatif menurunkan kadar gula darah. Desain penelitian ini adalah penelitian deskriptif. Populasinya sebanyak 125 responden, dengan sampel yang sesuai kriteria inklusi sebesar 70 responden. Tehnik sampling yang digunakan adalah simple random sampling. Data yang terkumpul, kemudian dilakukan analisa deskriptif proporsi presentase. Hasil penelitian didapatkan mahasiswa fisioterapi 51 responden yang mempunyai pengetahuan cukup (73\%), 10 responden (14, \%), baik dan 9 responden mempunyai tingkat pengetahuan kurang baik (13\%). Hal ini didukung karena tingkat pendidikan responden yang berbeda dan informasi yang didapat juga beragam. Masukan bagi Prodi Fisioterapi tetap meningkatkan pengetahuan dan kesadaran mahasiswa fisioterapi tentang insole sebagai alternatif menurunkan kadar glukosa darah melalui seminar ataupun pelatihan untuk memotivasi kembali mahasiswa fisioterapi meningkatkan pengetahuan.
\end{abstract}

Kata kunci: Tingkat pengetahuan, insole, kontraksi eksentrik dan diabetes mellitus tipe-2

\begin{abstract}
The recent study shows that there was a decrease in fasting blood glucose levels and post prandial blood glucose levels in the use of insole at an angle of $-10^{\circ}$ for 5 days. Based on the observation of researchers, not all physiotherapy students know about insole as an alternative to lowering blood sugar levels. This study identifies the level of knowledge (know) of physiotherapy students about insole as an alternative to lowering blood sugar levels. The design of this research is descriptive research. The population is 125 respondents, with 70 respondents samples fits the inclusion criteria. The sampling technique used is simple random sampling. The data collected is then analyzed using a descriptive proportion of the percentage. The results obtained by physiotherapy students 51 respondents who have sufficient knowledge (73\%), 10 respondents $(14, \%)$, good and 9 respondents have poor knowledge levels $(13 \%)$. This is supported by the differences of education level of respondents and the information obtained is diverse as well. The recommendation for Physiotherapy Study Program is tocontinues increasing the knowledge and awareness of physiotherapy students about insole as an alternative to lowering blood glucose levels through seminars or training for increasing physiotherapy students knowledge
\end{abstract}

Keywords: Knowledge level, insole, eccentric contraction and type 2 diabetes mellitus 


\section{PENDAHULUAN}

Pengetahuan merupakan hasil tahu setelah seseorang melakukan penginderaan pada obyek tertentu (Notoatmodjo, 2003). Fenomena mahasiswa prodi Fisioterapi, dimana masih banyak mahasiswa belum tahu tentang efek pemakaian insole terhadap penurunan kadar glukosa darah. Terjadi penurunan kadar glukosa darah puasa maupun kadar glukosa darah 2 jam post prandial setelah pemakaian insole dengan sudut kemiringan 10 derajat selama 5 hari (Dwianto H, 2017). Riset Kesehatan Dasar 2007 oleh Departemen Kesehatan melaporkan bahwa rata-rata angka kejadian diabetes mellitus di daerah urban untuk usia di atas 15 tahun sebesar 5,7\%. (Riskesdas, 2008). Hal ini dapat menyebabkan konsekuensi jangka pendek dan jangka panjang yang parah mulai dari kerusakan otak yang menyebabkan amputasi dan penyakit jantung (ADA, 2012).

Saat berjalan dengan memakai insole sepatu center of gravity (COG) tubuh bergeser ke depan menyebabkan tubuh cenderung jatuh ke depan sehingga menimbulkan beban yang lebih besar untuk ditopang, namun tubuh memiliki kemampuan mempertahankan diri agar tidak jatuh ke depan dan tetap berada pada posisi tegak (Porter, 2003). Hal tersebut terjadi akibat fungsi calf muscle yang berkontraksi secara eksentrik mengkompensasi berat tubuh dengan arah gaya yang berlawanan, sehingga kerja calf muscle lebih berat. Hal ini menyebabkan tubuh membutuhkan lebih banyak energi, di sisi lain menyebabkan ischemic reperfussion stress, pembuluh darah menyempit dan melebar berulang kali, menciptakan turbulensi aliran darah dan terjadi hipoksia local. Kondisi hipoksia meningkatkan pembentukan GLUT 1, sehingga ekspresi GLUT 1 pada membran plasma meningkat (Ciaraldi, et al., 2005). Kontraksi otot tipe eksentrik erat hubungannya dengan metabolisme otot dan pelepasan ion $\mathrm{Ca}^{2+}$ dari retikulum sarkoplasma. Ketika terjadi kontraksi eksentrik, jembatan silang miosin melekat dan protein aktin saling menjauh sehingga terjadi pemanjangan sarkomer. Pemanjangan ini juga menyebabkan retikulum sarkoplasma teregang dan mengeluarkan substansi ion kalsium. Pemanjangan ini juga menghasilkan tegangan pada sarkomer yang melibatkan protein aktin dan miosin (Bubbico, 2010). Kedua proses fisiologi kontraksi eksentrik ini yang akan memberikan stimulasi pada transporter glukosa fasilitatif sel otot, sehingga dapat meningkatkan ambilan glukosa darah otot.

Pendidikan, pekerjaan, umur, minat, pengalaman, kebudayaan, lingkungan sekitar dan informasi merupakan faktor-faktor yang mempengaruhi tingkat pengetahuan seseorang (Mubarak, 2007). Pengetahuan yang baik yang dimiliki oleh mahasiswa fisioterapi stikvinc tentang pemakaian insole sebagai alternatif menurunkan kadar glukosa darah dapat dikembangkan lebih jauh dalam memberikan latihan khususnya pada penderita diabetes mellitus sehingga pengetahuan di bidang ilmu fisioterapi semakin berkembang.

Berdasarkan uraian di atas, pengetahuan dapat diperoleh dan ditingkatkan melalui pemberian informasi seperti dengan memberikan pemahaman tentang pemakaian insole sebagai alternatif menurunkan kadar glukosa darah, sehingga mahasiswa termotivasi untuk mengembangkan latihan otot tipe eksentrik untuk penderita diabetes mellitus khususnya tipe-2.

\section{BAHAN DAN METODE}

Berdasarkan tujuan yang ingin dicapai pada penelitian ini peneliti menggunakan desain penelitian deskriptif. Desain penelitian ini adalah menggambarkan tingkat pengetahuan mahasiswa fisioterapi Stikvinc (tahu) insole sebagai alternatif menurunkan kadar glukosa darah.Populasinya yaitu semua mahasiswa fisioterapi Stikvinc tahun akademik 2018-2019 yang berjumlah 125 orang. Besar sampling sesuai populasi terjangkau yaitu 70 mahasiswa fisioterapi stikvinc.

Penelitian ini dilaksanakan setelah peneliti mendapatkan ijin dari Ketua Lembaga Penelitian dan Pengabdian Pada Masyarakat Stikvinc untuk melakukan pengumpulan data. Setelah dilakukan analisa data secara statistik deskriptif proporsi prosentase maka diperoleh hasil akhir berapa prosentase jumlah responden yang mempunyai tingkat pengetahuan cukup, baik dan kurang.

\section{HASIL}

\section{Data Umum}

Data umum menggambarkan karateristik responden berdasarkan usia, tingkat pendidikan dan pernah tidaknya memperoleh informasi tentang pemakaian insole sebagai alternatif menurunkan kadar glukosa darah. 
1.1 Karakteristik Responden Berdasarkan Usia

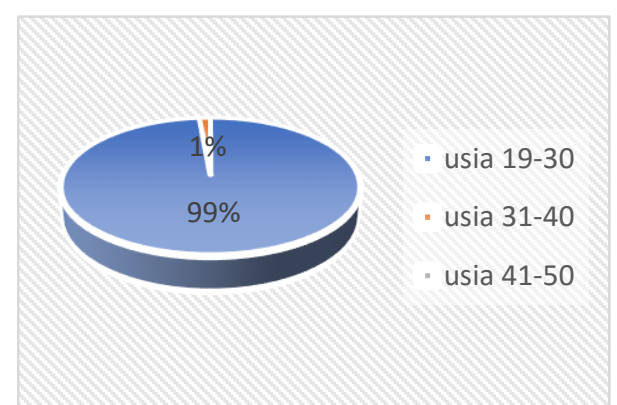

Diagram Pie 1.1 Distribusi Frekwensi Responden Berdasarkan Usia di Program Studi Fisioterapi

Berdasarkan Diagram Pie 1.1 di atas menunjukkan bahwa mahasiswa yang menjadi responden sebagian besar berusia $19-30$ tahun (99\%)

1.2 Gambaran Responden Berdasarkan Tingkat Pendidikan

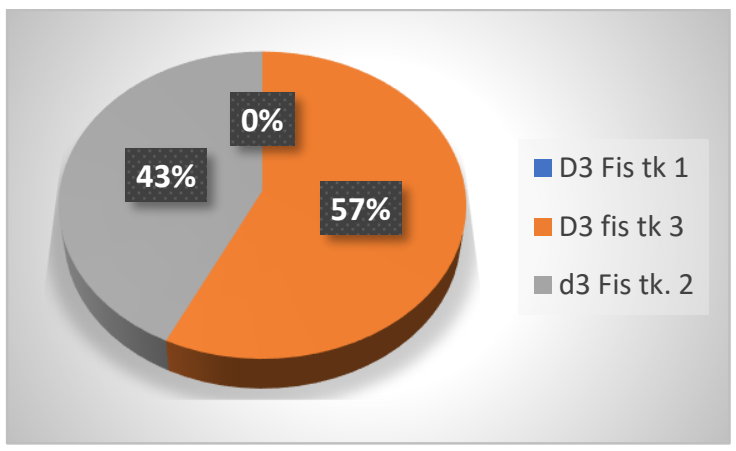

Diagram Pie 1.2 Distribusi Frekwensi Responden Berdasarkan Tingkat Pendidikan di Program Studi Fisioterapi

Berdasarkan Diagram Pie 1.2 menggambarkan sebagian besar responden memiliki pendidikan tingkat $3(57 \%)$ dan tingkat $2(43 \%)$ dan tingkat I tidak menjadi responden.

1.3 Karakteristik Responden Berdasarkan Tahu atau Tidak Tahu tentang Insole

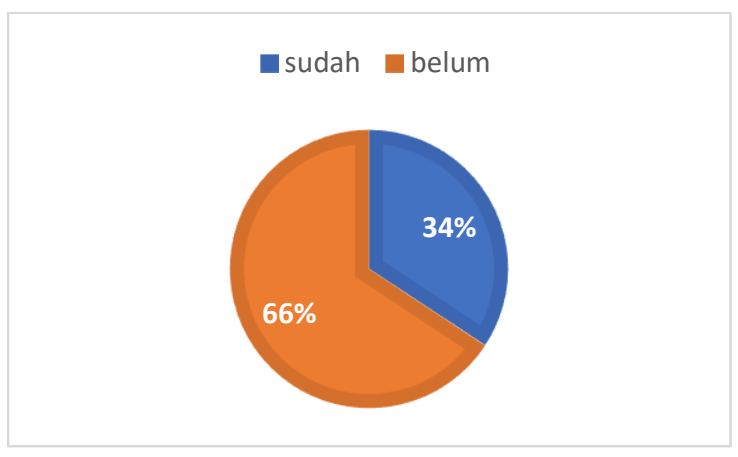

Diagram Pie 1.3 Distribusi Frekwensi Responden Berdasarkan Tahu dan Tidak Tahu Tentang Insole

Berdasarkan Diagram Pie 1.3 di atas menunjukkan bahwa tahu tentang insole 24 responden (34\%) dan tidak tahu 46 responden $(66 \%)$.

\subsection{Gambaran Responden Berdasarkan Sumber Informasi}

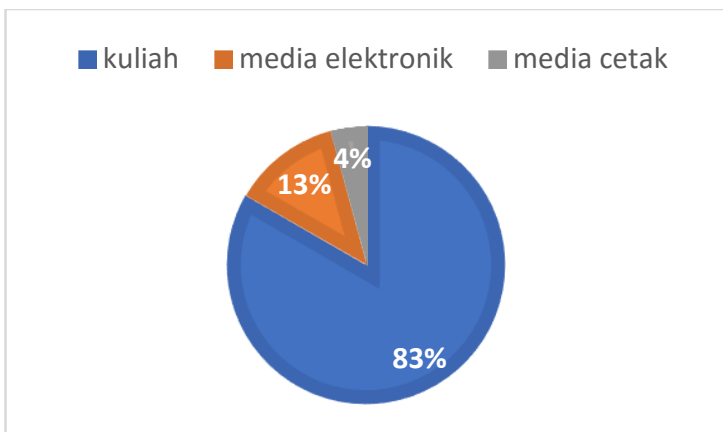

Diagram Pie 1.4 Distribusi frekwensi responden Berdasarkan Sumber Informasi di Program Studi Fisioterapi

Berdasarkan Diagram Pie1.4 menggambarkan 24 responden yang tahu tentang insole sumbernya dari kuliah $83 \%, 13 \%$ dari media elektrolika dan $4 \%$ dari media cetak

\section{Data Khusus}

Data khusus ini menggunakan tingkat pengetahuan mahasiswa Program Studi Fisioterapi tentang insole sebagai alternatif menurunkan kadar glukosa darah.

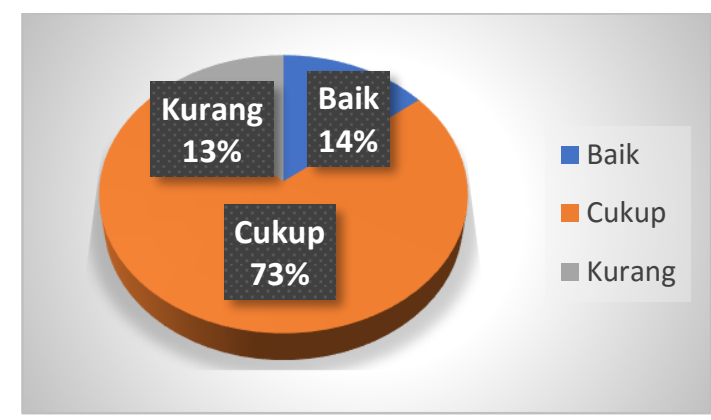

Diagram Pie 1.5 Distribusi frekwensi Responden Berdasarkan Tingkat Pengetahuan di Prodi Fisioterapi

Berdasarkan diagram pie 1.5 di atas menunjukkan hasil analisa frekwensi jawaban responden berdasarkan kreteria tingkat pengetahuan yang dimiliki mahasiswa tentang 
insole sebagai alternatif menurunkan kadar glukosa darah. Analisa frekwensi jawaban responden menunjukkan bahwa mahasiswa fisioterapi Stikvinc 51 responden yang mempunyai pengetahuan cukup 73\%, 10 responden $(14, \%)$, baik dan 9 responden mempunyai tingkat pengetahuan kurang baik $(13 \%)$.

\section{PEMBAHASAN}

Dari 70 responden terdapat 51 responden $(73 \%)$ yang berpengetahuan cukup. Ditinjau dari sumber informasi selain dari kuliah, responden juga memperoleh sumber informasi dari media elektronik $6 \%$ dan dari media cetak $2 \%$ responden. Informasi adalah salah satu dari beberapa faktor yang mempengaruhi tingkat pengetahuan (Mubarak. et.all, 2007). Seseorang dengan mudah memperoleh pengetahuan yang baru, bila mendapatkan informasi dengan cepat. Antara teori dan fakta ada keseuaian, dimana informasi dari media elektronik dan media cetak sangat mudah untuk diperoleh yang dapat meningkatkan pengetahuan seseorang. Pada kenyataannya banyak responden yang mempunyai HP yang ada wi-finya yang bisa dibuat untuk browsing.

Dari 70 responden terdapat 9 responden (13\%) yang berpengetahuan kurang. Dilihat dari sumber informasi yaitu ada 46 responden $(66 \%)$ belum pernah mengetahui tentang insole sebagai alternatif menurunkan kadar glukosa darah. Menurut Mubarak.et.all (2007) Pengalaman merupakan salah satu faktor yang mempengaruhi tingkat pengetahuan. Suatu kejadian yang pernah dialami seseorang dalam berinteraksi dengan lingkungannya disebut pengalaman. Kecenderungan seseorang akan berusaha untuk melupakan, bila mendapatkan pengalaman kurang baik, namun jika mendapat pengalaman yang menyenangkan maka secara psikologis akan timbul kesan yang sangat mendalam dan membekas dalam emosi kejiwaannya , akhirnya membentuk sikap positif dalam kebudayaannya. Berdasarkan hasil diatas peneliti memperoleh kesesuaian antara teori dan fakta, dimana seseorang dengan pengalaman membaca informasi. Berdasarkan pengamatan peneliti bahwa hasil Penelitian perlu disosialisasikan ke mahasiswa sehingga mahasiswa akan termotivasi untuk membaca penelitian sebagai pengetahuan yang baru, sehingga bisa berkembang pengalaman mendapat informasi.
Dari 70 responden didapatkan 10 responden $(14 \%)$ yang berpengetahuan baik. $100 \%$ responden mempunyai tingkat pendidikan setaraf perguruan tinggi (D3). Menurut Mubarak.et.all (2007) pendidikan merupakan salah satu faktor yang mempengaruhi pengetahuan. Pendidikan berarti Proses bimbingan yang diberikan seseorang pada orang lain terhadap sesuatu hal agar mereka dapat memahami disebut pendidikan. Berdasarkan hasil diatas didapatkan kesesuaian antara teori dan fakta. Seseorang semakin tinggi pendidikannya, maka semakin mudah seseorang menerima informasi dan akhirnya makin banyak pula pengetahuan yang dimiliki. Dalam hal ini pendidikan responden adalah setaraf perguruan tinggi dan semua responden sudah pernah mendapat informasi sehingga akan semakin baik pula tingkat pengetahuan seseorang.

\section{SIMPULAN}

Hasil dari penelitian dengan judul "Gambaran Tingkat Pengetahuan Mahasiswa Fisioterapi Stikvinc Tentang Insole Sebagai Alternatif Menurunkan Kadar Glukosa Darah" dapat disimpulkan bahwa mayoritas responden berpengetahuan cukup yaitu sebanyak $73 \%$, dan $14 \%$ berpengetahuan baik serta $13 \%$ berpengetahuan kurang

\section{SARAN}

Diharapkan semua prodi di Stikes Katolik St. Vincentius a Paulo Surabaya mengadakan pembekalan berkelanjutan melalui seminar ataupun pelatihan tentang insole sebagai solusi untuk pasien diabetes mellitus dalam penurunan kadar glukosa darah dan bagi prodi fisioterapi menindak lanjuti penelitian selanjutnya yang berkaitan dengan pemakaian insole.

\section{DAFTAR PUSTAKA}

American Diabetes Association., 2012. Diagnosis and Classification of Diabetes Millitus., Diabetes Care Volume 35 Supplement 1:64-71

Bubbico A and Kravitz L, 2010. Eccentric Exercise: A Comprehensive Review of a Distinctive Training Method. IDEA Fitness Journal. Vol. 7 No. 9, pp. 50-59

Ciaraldi T P, Mudaliar S, Barzin A, Macievic J A, Edelman S V, park K S, Henry R R, 2005. 'Skeletal muscle glut 1 
transporter protein expression and basal leg glucose uptake are reduced in type 2 diabetes'. The Journal of Clinical Endocrinology \& Metabolism 90(1)

Dwianto H, 2017; Pengaruh Pemakaian Insole Terhadap Kadar Glukosa Darah Penderita Diabetes Mellitus Tipe-2, Departemen Ilmu Faal Fakultas Kedokteran Universitas Airlangga

Mubarak, Iqbal Wahit. 2007. Promosi Kesehatan: Sebuah Pengantar Proses Belajar Mengajar dalam Pendidikan. Ed. 1, Yogyakarta: Graha Ilmu
Notoatmodjo, Soekidjo. 2003. Pendidikan dan Perilaku Kesehatan. Jakarta: Rineka Cipta Nursalam. 2008. Konsep dan Penerapan Metodologi Penelitian Ilmu Keperawatan: Pedoman Penelitian, Tesis dan Instrumen Penelitian Keperawatan. Ed. 2, Jakarta: Salemba Medika

Porter Stuart B, 2003. Tidy's physiotherapy: thirteenth edition. Buttenworth Heineman: United Kingdom

Riskesdas,2008:Laporan Nasional 2007, Badan Penelitian dan Pengembangan Kesehatan Depkes RI 